\title{
CAN MANGROVES HELP COMBAT SEA LEVEL RISE THROUGH SEDIMENT ACCRETION AND ACCUMULATION?
}

\author{
Hoque M. M. ${ }^{*}$, Abu Hena M. K. ${ }^{1}$, Ahmed O. H. ${ }^{2}$, Idris M. H. ${ }^{1}$, Hoque A. T. M. \\ Rafiqul $^{3}$, Billah M. M. ${ }^{1}$ \\ ${ }^{1}$ Department of Animal Science and Fishery, Universiti Putra Malaysia Campus Bintulu, 97008 Bintulu, \\ Sarawak, Malaysia. \\ ${ }^{2}$ Department of Crop Science, Universiti Putra Malaysia Campus Bintulu, 97008 Bintulu, Sarawak, Malaysia. \\ ${ }^{3}$ Institute of Forestry and Environmental Sciences, Chittagong University, Chittagong 4331, Bangladesh. \\ *Corresponding author: hoque_doe@yahoo.com
}

\begin{abstract}
Mangroves have substantial roles to induce sedimentation in the vulnerable coastal regions, which subsequently helps to combat climate change induced impacts like sea level rise. Although Sarawak has numerous pristine estuarine mangroves, studies on the roles of these mangroves in regards to sediment deposition are scanty. Therefore, this study was carried out to determine the sediment accretion and accumulation pattern of pristine Sibuti mangrove using tiles and sediment traps from January to December 2013. Monthly average accretion and accumulation rate of sediments of this mangrove were $0.55 \mathrm{~mm}$ and $0.08 \mathrm{~g} \mathrm{~cm}^{-2}$, respectively. A total of 6.56 $\mathrm{mm}$ and $0.93 \mathrm{~g} \mathrm{~cm}^{-2}$ sediments were accreted and accumulated annually. Significantly positive correlation $(\mathrm{r}=0.794)$ was found for the monthly accretion of sediments with accumulation. Accretion and accumulation of sediments were also positively correlated with rainfall. Comparatively higher rate of accretion and accumulation of sediments were estimated in the months of wet season when the rainfall and tidal inundation duration were high. Erosion was found higher in the months of dry season when the rainfall was low. Seasonal variations were not found for sediment accretion as well as accumulation in the study area. The findings of the study suggest that the roles of this forest in regards to sediment accretion through retention is compatible with the predicted annual rate of sea level rise of 1.8 to $5.9 \mathrm{~mm}$ within $21^{\text {st }}$ century by IPCC.
\end{abstract}

(Keywords: Sediment accretion, Sediment accumulation, Sea level rise, Sibuti mangrove, Sarawak)

\section{INTRODUCTION}

There are numerours evidence that mangroves are one of the most productive and valuable ecosytem lying between land and sea especially in the tropical and sub-tropical region $[1,2]$. Out of numerous functions, the most remarkable function of this ecosytem to coastal environment is to provide a suitable technique for trapping sediments, and due to afforementioned reason it is a recognized ecosytem that retains and accumulate suspended sediments [3$6]$. Sediment accretion means the accumulation of suspended sediments rich in organic and inorganic materials borne by tidal water during high tide [2, 7]. These suspended materials settle down in the forest floor during low tide, while the velocity of waterflow is very low $[2,6]$. Besides, the unique and complex structure of mangrove trees having prop roots, knee roots and pneumatophore reduces the velocity of tidal flow and thus trap sediments which eventually plays key role in land building process $[2$, $8-11]$. Pristine and undisturbed mangroves are able to trap and retain more than $80 \%$ of tidal sediments [6]. In most of the studies, the annual rate of sedimentaion in mangrove areas were found within 1-8 $\mathrm{mm}[12]$.

Global warming is the important issue at present throughout the world and has strong relation to sea live rise (SLR) $[13,14]$. Besides, sea level rise is a severe threat for the existence of many mangroves in the coming decades $[15,16]$. The existence of mangroves in future will mostly depend on their accretion and retention/deposition capability of sediments to combat upcoming prediction of sea level rise $[8,15,17,18]$. Due to global warming, the projected rate of global sea level rise (GSLR) is expected to be 1.8 to $5.9 \mathrm{~mm} \mathrm{yr}^{-1}$ by 2100 [19]. However, this projection is completely based on global perspective, the local or regional changes of sea level may vary from this projection [20, 21]. National Hydraulic Research Institute of Malaysia (NAHRIM) reported that due to local climate and topographical conditions, the regional sea level rise in Malaysia is expected to be higher [22]. They predicted the observed mean SLR rate along the Malaysian coast (based on satellite altimetry data from 1993-2010) is within 2.7-7.0 $\mathrm{mm} \mathrm{yr}^{-1}$. However, in Miri, Sarawak the projected SLR for the year of 2100 is $5.23 \mathrm{~mm} \mathrm{yr}^{-1}$.

In Malaysia, there are about 5,77,500 ha of mangroves forest reserves and Sarawak is the second largest estate that covers $23 \%$ of the total mangrove forests [23]. The mangroves of Sarawak are mostly found 
along the coastlines [24, 25]. The studies conducted on Malaysian mangroves were mostly on standing biomass, productivity, litter dynamics, nutrient flux [26-30] and few studies were on sedimentation $[31,32]$ that focused completely on mangroves of Peninsular Malaysia. Although Sarawak mangroves are mostly found in coastlines, very few researches have yet been conducted to explore the geomorphological roles of these mangroves considering the GSLR. This leads to incomplete understanding of mangroves function in Sarawak. Therefore, this study was carried out to determine the sediment accretion and accumulation pattern of Rhizophora apiculata dominated mangrove [33] of Sibuti, an important and undisturbed mangrove [34] of Sarawak, Malaysia. The outcome of this study would be helpful to quantify the land building pattern of Sarawak mangroves in regards to projected estimation of GSLR.

\section{MATERIALS AND METHODS}

\section{Study Area}

Sibuti mangrove forest $\left(3^{\circ} 59^{\prime} 25.76^{\prime \prime} \mathrm{N}\right.$ and $\left.113^{\circ} 43^{\prime} 51.6^{\prime} \mathrm{E}\right)$ is located at the edge of South China Sea, approximately $45 \mathrm{~km}$ West of Miri town, Sarawak, Malaysia (Figure 1). The forest is bounded by Bungai farmlands on the North and Sibuti river at the South and East. This is an undisturbed tropical mangrove forest dominated by $R$. apiculata [33] followed by Xylocarpus granatum and Nypa fruticans. The forest is regularly inundated by normal high tide and was found to be inundated averagely 34 times per month [35]. Therefore, the forest is under classification-3 [36]. The estuary is semi-diurnal and tidal range varied between 0.2 to 2 $\mathrm{m}$ during neap and spring tide [35]. From the river bank to inner side, the whole forest is almost flat with modest increase of elevation at the edge of the forest.

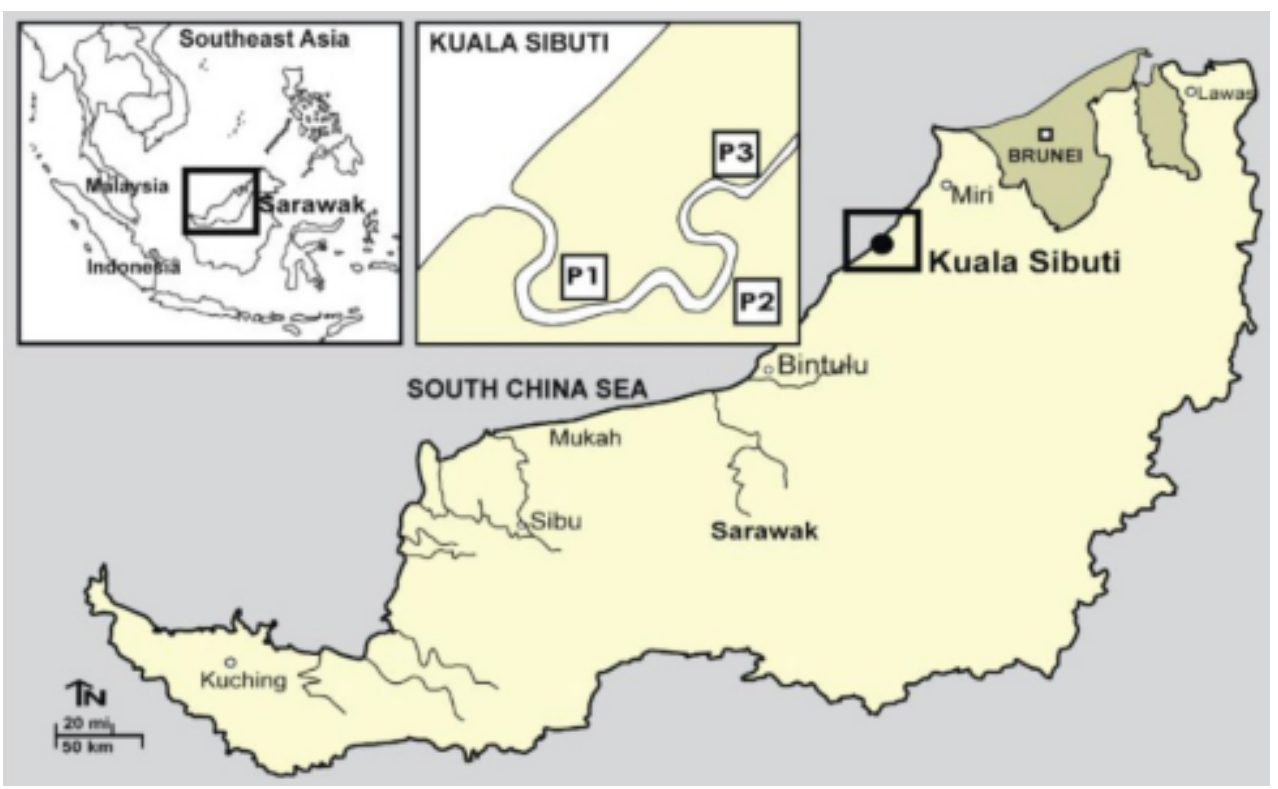

Figure 1. Location of the study area showing sample plots in the Sibuti mangrove forest, Miri, Sarawak.

\section{Collection of Sample}

Three sampling plots, each $100 \mathrm{~m} \times 100 \mathrm{~m}$ (river estuary, middle and last part of the forest) were purposively selected considering the structure, density and topography of the forest to gather overall information about the forest. A total of nine solid tiles $\left(30 \mathrm{~cm}^{2}\right.$; three replicates in each sampling plot) were placed horizontally at $5 \mathrm{~cm}$ depth from the sediment surface and marked by flags following the methods of Mahmood et al. [32] and Christiansen et al. [37]. Initial sediment height ( $\mathrm{mm})$ on each tile was recorded monthly from January to December 2013. Monthly accretion and erosion were estimated by deducting the sediment height on the same tile base of preceding month. 
Similarly nine sets (each set attached with three traps) of sediment traps (three replicates in each sampling plot) were set up $10 \mathrm{~cm}$ above the forest floor [38] and the sediment traps were collected and replaced by new sets monthly and brought back to laboratory for further processing. The traps sediments were filtered by Oil-less Vacuum Pumps (Model: Rocker 300; Rocker Scientific Co., Limited, Taiwan) and oven dried at $60^{\circ} \mathrm{C}$ until the constant weight of the samples were attained. The dried samples were then weighed to nearest gram and then calculated to $\mathrm{g} \mathrm{cm}^{-2}$.

\section{Statistical Analysis}

Monthly mean values of sediment accretion as well as accumulation were calculated considering the three seasons [39] namely, Intermediate (JanuaryApril), Dry (May-August), and Wet (SeptemberDecember). Seasonal variation of total accreted and accumulated sediments were compared by one way analysis of variance (ANOVA) followed by Tukey's test using SAS 9.2 version. Pearson correlation coefficient was performed to determine the influence of climatic and hydro parameters (temperature, rainfall, tidal frequency and inundation duration) on monthly sediment accretion and accumulation.

\section{RESULTS}

\section{Climatic and Hydro Parameters}

The monthly temperature, rainfall, tidal frequency and inundation duration that influence sediment accretion/erosion and accumulation are shown in Table1. Significant seasonal variations were not found in monthly mean temperature, monthly total rainfall, tidal frequency and inundation duration throughout the year. The highest tidal frequency was calculated in intermediate season especially in March (41 times) and April (40 times), whereas the lowest frequency was observed in the months of dry season especially in June (30 times) and May (31 times). The tidal inundation duration that flooded the study area was recorded highest in May (263 hrs) followed by December (261 hrs), April (238 hrs) and October (236 hrs), whereas, the lowest tidal inundation duration was found in February (200 hrs) followed by August ( $217 \mathrm{hrs})$, September $(217$ hrs) and March (219 hrs). The lowest rainfall was recorded in August $(101.3 \mathrm{~mm})$ of dry season and highest rainfall was recorded in December (691.2 $\mathrm{mm}$ ) of wet season (Figure 2).

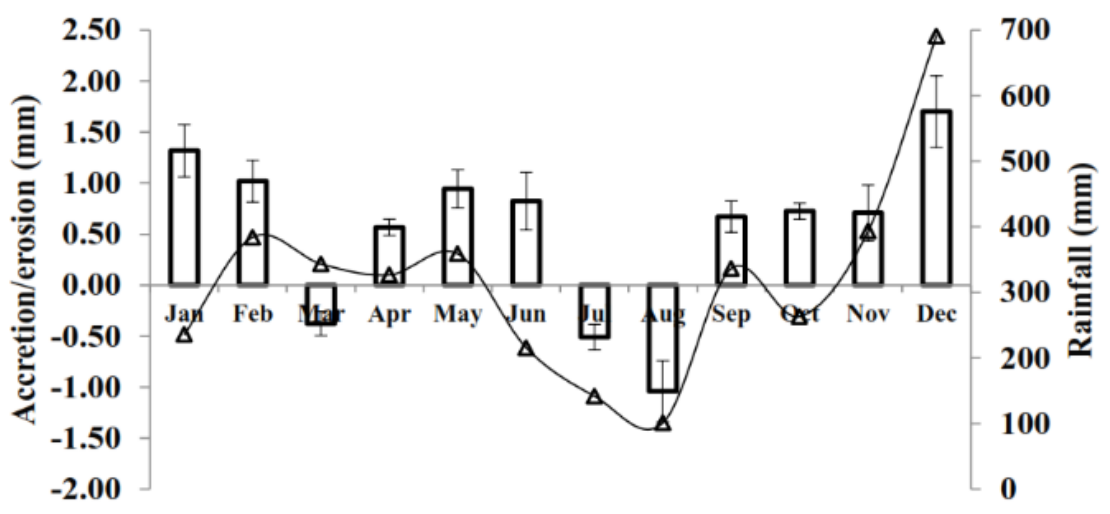

$\square$ Accretion/erosion (mm) $\triangle$ Rainfall (mm)

Figure 2.Relation between month wise sediment accretion/erosion and rainfall of Sibuti Mangrove, Sarawak.

Table 1. Climatic and hydro-parameters of Sibuti mangrove during the study period.

\begin{tabular}{lllllllllllll}
\hline Climatic/hydro-parameters & Jan & Feb & Mar & Apr & May & June & July & Aug & Sept & Oct & Nov & Dec \\
\hline Total rainfall $(\mathrm{mm}) \dagger$ & 236.4 & 384.4 & 343.5 & 326.8 & 359.0 & 215.8 & 141.8 & 101.3 & 336.5 & 263.6 & 393.7 & 691.2 \\
Mean Temp $\left({ }^{\circ} \mathrm{C}\right) \dagger$ & 27.9 & 28.5 & 28.7 & 28.8 & 28.8 & 28.9 & 28.4 & 28.5 & 28.2 & 28.0 & 28.2 & 28.2 \\
Tidal frequency (times)\# & 34 & 32 & 41 & 40 & 31 & 30 & 33 & 33 & 34 & 41 & 32 & 32 \\
Total tidal inundation (hr)\# & 229 & 200 & 219 & 238 & 263 & 243 & 222 & 217 & 217 & 236 & 235 & 261 \\
\hline
\end{tabular}

Source: $\uparrow$ stands for source: Meteorological Department, Niah Forest Research Station, Miri, Sarawak, Malaysia, and \# stands for source: The Director of Marine Sarawak, Malaysia (DOMSM), 2013. Sarawak Hourly High and Low Tide Tables (Including Standard Ports of Sabah). The Sarawak Marine Department (SMD), Malaysia. 


\section{Sediment Accretion and Erosion}

Monthly sediment erosion and accretion of Sibuti mangrove were within -1.04 and $1.72 \mathrm{~mm}$. The highest accretion rate was recorded in December $(1.72 \mathrm{~mm})$ followed by January $(1.32 \mathrm{~mm})$, February $(1.02 \mathrm{~mm})$, May $(0.94 \mathrm{~mm})$, June $(0.83$ $\mathrm{mm})$, October $(0.73 \mathrm{~mm})$, September $(0.67 \mathrm{~mm})$ and April $(0.57 \mathrm{~mm})$. The erosion rate was recorded highest in August $(-1.04 \mathrm{~mm})$ followed by July $(-0.51 \mathrm{~mm})$ and March (-0.38 mm; Figure 2). A total of $6.56 \mathrm{~mm}$ sediment was accreted annually with monthly average of $0.55 \mathrm{~mm}$ in this mangrove forest during the study period. The rate of accretion was comparatively higher in wet season than that of dry and intermediate seasons, whereas, the rate of erosion was found vice-versa, although no significant variations were found $(d f=2, f=1.47$, $p=0.28$ ) among the seasons. Monthly accretion and accumulation rate of sediments was positively correlated $(r=0.79, p<0.05)$ and related to the rainfall $(r=0.67, p<0.05)$. The sediment accretion rate was not related to the temperature, monthly tidal frequency as well as inundation duration that flooded the mangrove ecosystem (Table 2).

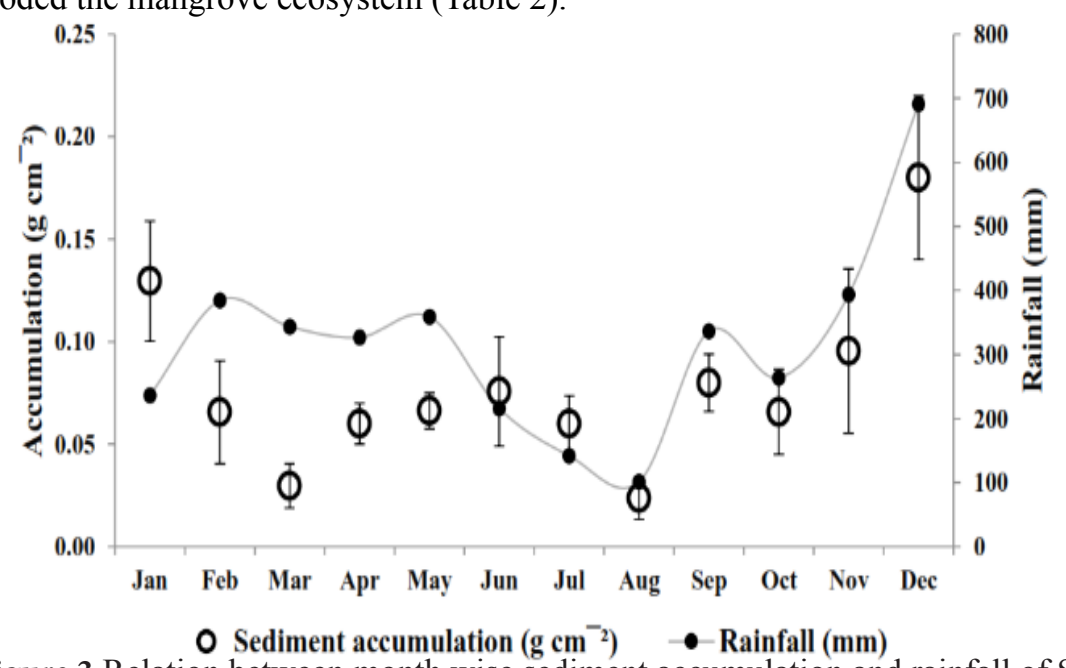

Figure 3.Relation between month wise sediment accumulation and rainfall of Sibuti Mangrove, Sarawak.

Table 2. Pearson correlation coefficients among sediment accretion and accumulation with climatic and hydro-parameters of Sibuti mangrove, Sarawak.

\begin{tabular}{|c|c|c|c|c|c|c|}
\hline & $\begin{array}{l}\text { Accretion } \\
(\mathrm{mm})\end{array}$ & $\begin{array}{l}\text { Accumulation } \\
\left(\mathrm{g} \mathrm{cm}^{-2}\right)\end{array}$ & $\begin{array}{l}\text { Tidal Frequency } \\
\text { (times) }\end{array}$ & $\begin{array}{l}\text { Tidal } \\
\text { inundation (hr) }\end{array}$ & $\begin{array}{l}\text { Rainfall } \\
(\mathrm{mm})\end{array}$ & $\begin{array}{l}\text { Mean Temp } \\
\left({ }^{\circ} \mathrm{C}\right)\end{array}$ \\
\hline Accretion $(\mathrm{mm})$ & - & & & & & \\
\hline Accumulation $\left(\mathrm{g} \mathrm{cm}^{-2}\right)$ & $0.79 * *$ & - & & & & \\
\hline Tidal Frequency (times) & $-0.17^{\mathrm{ns}}$ & $-0.35^{\text {ns }}$ & & & & \\
\hline Tidal inundation (hr) & $0.49^{\text {ns }}$ & $0.51^{\mathrm{ns}}$ & $-0.17^{\mathrm{ns}}$ & - & & \\
\hline Rainfall (mm) & $0.67^{*}$ & $0.69^{*}$ & $-0.08^{\mathrm{ns}}$ & $0.44^{\mathrm{ns}}$ & - & \\
\hline Mean temp $\left({ }^{\circ} \mathrm{C}\right)$ & $-0.19^{\text {ns }}$ & $-0.49^{\text {ns }}$ & $-0.09^{\text {ns }}$ & $0.16^{\mathrm{ns}}$ & $-0.15^{\mathrm{ns}}$ & - \\
\hline
\end{tabular}

\section{Sediment Accumulation}

Monthly sediment accumulation rate in Sibuti mangrove ranged from 0.02 to $0.18 \mathrm{~g} \mathrm{~cm}^{-2}$. The highest accumulation was recorded in December $\left(0.18 \mathrm{~g} \mathrm{~cm}^{-2}\right)$ followed by January $\left(0.13 \mathrm{~g} \mathrm{~cm}^{-2}\right)$, November $\left(0.10 \mathrm{~g} \mathrm{~cm}^{-2}\right)$, June and September $(0.08$ $\left.\mathrm{g} \mathrm{cm}^{-2}\right)$, February, May, October $\left(0.07 \mathrm{~g} \mathrm{~cm}^{-2}\right)$, April, July $\left(0.06 \mathrm{~g} \mathrm{~cm}^{-2}\right)$, March $\left(0.03 \mathrm{~g} \mathrm{~cm}^{-2}\right)$ and August $\left(0.02 \mathrm{~g} \mathrm{~cm}^{-2}\right)$. The lowest accumulation was recorded in August $\left(0.02 \mathrm{~g} \mathrm{~cm}^{-2}\right)$ followed by March $\left(0.03 \mathrm{~g} \mathrm{~cm}^{-2}\right)$, April, July $\left(0.06 \mathrm{~g} \mathrm{~cm}^{-2}\right)$, and February, May, October $\left(0.07 \mathrm{~g} \mathrm{~cm}^{-2}\right)$ (Figure 3). Annually, $0.93 \mathrm{~g} \mathrm{~cm}^{-2}$ sediments were accumulated with the monthly average of $0.08 \mathrm{~g} \mathrm{~cm}^{-2}$ in this mangrove forest. Sediments accumulated in the wet season was higher than the intermediate and dry seasons, however the seasonal changes of accumulation was not significant $(d f=2, f=1.60, p=0.25)$. Similar to sediment accretion, monthly sediment accumulation rate was also positively related $(r=0.69, p<0.05)$ with monthly rainfall (Table 2).

\footnotetext{
${ }^{* *}$ Significant at $\mathrm{P}<0.01 ; \quad$ ns; not significant at $\mathrm{P}>0.05 ; \quad{ }^{*}$ significant at $\mathrm{P}<0.05 ; \mathrm{n}=12$.
} 


\section{DISCUSSION}

A significant relation was found between monthly sediment accretion and accumulation. The highest accretion $(1.72 \mathrm{~mm})$ was recorded in December, followed by January, February, and May when the monthly rainfall was comparatively higher along with higher tidal inundation duration that flooded the mangrove ecosystem. In contrast, the erosion rate was higher in dryer months especially in August $(-1.04 \mathrm{~mm})$ when the rainfall and tidal inundation duration were relatively low (Figure 2; Table 1). This indicates that rainfall has profound influence on sediment accretion in mangrove ecosystems. The finding of the present study showed the similar pattern of accretion that was observed in other tropical mangrove ecosystems [32]. Besides, the topography of the forest floor is almost flat with very little variation at the edge of the forest. Moreover, the canopy of the forest is almost closed. So the raindrops can not directly hit the forest floor.The higher accretion during the afforementioned months when maximum sediments were accumulated may also be due to the flat topograpghy of the forest floor and canopy closure. Accretion/erosion rate of sediment in this mangrove ecosystem followed the monthly trend of sediment accumulation, which indicates that nature itself maintains a balance and logical pattern in regards to sediment accretion through accumulation in a mangrove ecosystem (Figure 4). The relationship between accretion and sedimentation in the present study is in agreement with the findings of Hedges and Keil [40]. Acceleration of land building process through elevated sedimentation in mangroves was reported by Mahmood et al. [32] in a protected mangrove forest of Kuala Selangor, Malaysia. Due to successive sedimentation in a mangrove ecosystem, land surface increases through sediment retention and the complex structure and root system of mangroves accelerate this process by enhancing the friction along with the reduction of tidal current speed $[4,41]$.

Generally, the rate of sediment deposition depends on the tidal frequency and its duration that flooded the mangrove ecosystem $[42,43]$. In the present study, monthly tidal frequency and inundation duration that flooded the study area were not remarkably varied throughout the year. During the study period, it was hypothesized that the most relevant and influencing hydro-parameters especially tidal frequency and it's duration of flooding might have significant influence on the rate of sediment accretion and accumulation. But after correlating the variables with the monthly rate of sediment accretion and accumulation, it was not found as important as speculated at the beginning (Table 2). Similar results were also reported by Cahoon and Lynch [44] from the three forest types of southwestern Florida, U.S.A. They did not find any influence of tidal duration that flooded the area on sediment accretion. The insignificant correlation may be due to the negligible and less fluctuation of hydro parameters of the study area. Sediment accretion and accumulation vary from mangroves to mangroves especially due to variation of species composition and tree density [2, 32]. Avicennia and Rhizophora dominated mangroves have the higher rate of sediment accreting and accumulating capacity due to their unique criteria of root systems i.e. pneumatophore, knee roots and prop/stilt roots that induce sedimentation process by creating physical barrier as well as reducing the velocity of tidal current [2]. Rhizophora experiences higher tidal velocity along with higher tidal duration due to the growing nature in the river bank areas [2]. The accretion and accumulation of sediments in this study area may be influenced by the dominancy of $R$. apiculata rather than hydro parameters influences.

The annual rate of sediment accretion of this study area is comparable with other $R$. apiculata dominated mangroves of the world especially of Malaysia (Table 3). This result also supports the sediment trapping capacity and pattern of $R$. apiculata dominated mangroves throughout the world. Bacon [49] and Snedaker et al. [50] reported that in most of the cases mangroves are keeping pace with the rate of sea level rise. However, long term and extensive research is essential for this kind of prediction and comparison. 


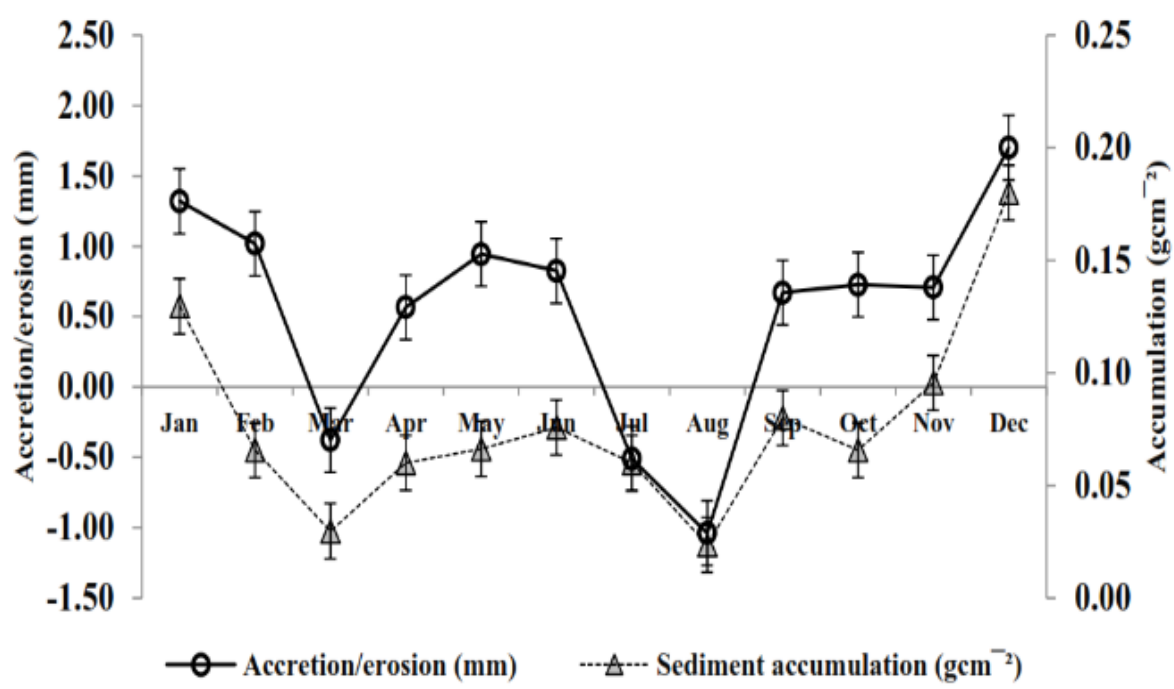

Figure 4. Relation between month wise sediment accretion/erosion and sediment accumulation of Sibuti Mangrove, Sarawak.

Table 3. Comparison of annual sediment accretion in various mangroves of the world.

\begin{tabular}{llcc}
\hline Location & Dominant species & $\begin{array}{c}\text { Accretion rate } \\
\left(\mathbf{m m} \mathbf{~ y r}^{-1}\right)\end{array}$ & Source \\
\hline Mexico & Rhizophora sp. & 3.00 & {$[45]$} \\
Northern Australia & Rhizophora sp. & 6.00 & {$[46]$} \\
Kuala Kemaman, Terengganu, Malaysia & Rhizophora sp. & $6.4-14.6$ & {$[47]$} \\
Bebar River Mangrove, Pahang, Malaysia & - & 5.3 to 5.4 & {$[48]$} \\
Setiu Mangrove, Malaysia & - & 6.10 & {$[31]$} \\
Kuala Selangor, Malaysia & Bruquiere parviflora & 10.20 & {$[32]$} \\
Sibuti Mangrove, Sarawak, Malaysia & Rhizophora sp & 6.56 & This study \\
\hline
\end{tabular}

\section{CONCLUSION}

Sibuti mangrove forest located at the mouth of South China Sea is possible to be affected by the consequences of global warming as well as sea level rise. Annual rate of sediment accretion of this mangrove forest is $6.56 \mathrm{~mm}$. The projected annual rate of global sea level rise for the year 2100 by IPCC is 1.8-5.9 mm [19] and by National Hydraulic Research Institute of Malaysia (NAHRIM) for Miri, Sarawak is $5.23 \mathrm{~mm}$ [22]. So our study clearly suggests that Sibuti manroves is quite capable to combat predicted sea level rise by IPCC and NAHRIM through sediment accretion and accumulation. This result will also provide baseline information of a pristine mangrove in regards to sedimentation. Long term research including various influencing parameters may develop a model of sedimentation process for the coastal area of the tropical region. The information of sediment accreting and accumulating pattern of this pristine mangrove ecosystem of Sarawak would be useful to the national and international community for realizing the importance of mangroves to compare and combat future sea level rise (SLR).

\section{ACKNOWLEDGEMENT}

Authors acknowledge the Department of Animal Science and Fishery, UPM Campus Bintulu 
Sarawak for providing facilities and Malaysian Government for providing partial funds through Project No. 04-01-04SF1422. Thanks to Mr. Khurshid Alam Bhuiyan for preparing the study area map.

\section{REFERENCES}

1. Kathiresan K. and Bingham B. L. (2001). Biology of mangroves and mangrove ecosystems. Advances in Marine Biology 40: 81-251.

2. Kathiresan K. (2003). How do mangrove forests induce sedimentation? Revista de Biologia Tropical 51: 355-360.

3. Woodroffe C. (1992). Mangrove sediments and geomorphology. In: Tropical Mangrove Ecosystem (eds. Robertson A.I. and Alongi D.M.) American Geophysical Union, Washington D.C. pp. 7-41.

4. Wolanski E., Mazda Y. and Ridd P. (1992). Mangrove hydrodynamics. In: Tropical Mangrove Ecosystem (eds. Robertson A.I. and Alongi D.M.) American Geophysical Union, Washington D.C. pp. 436-462.

5. Wolanski E. (1995). Transport of sediment in mangrove swamps. Hydrobiologia 295: 31-42.

6. Furukawa K., Wolanski E. and Mueller H. (1997). Currents and sediment transport in mangrove forests. Estuarine, Coastal and Shelf Science 44: 301-310.

7. Gross M. G. (1972). Oceanography a View of Earth. New Jersey: Prentice-Hall, England Wood Cliffs.

8. McKee K. L., Cahoon D. R. and Ilka C. F. (2007). Caribbean mangroves adjust to rising sea level through biotic controls on change in soil elevation. Global Ecology and Biogeography 16: 545-556.

9. Ellison J. C. (2008). Long-term retrospection on mangrove development using sediment cores and pollen analysis: a review. Aquatic Botany 89: 93-104.

10. Willard D. A. and Bernhardt C. E. (2011). Impacts of past climate and sea level change on Everglades wetlands: placing a century of anthropogenic change into a late-Holocene context. Climatic Change 107: 59-80.

11. Krauss K. W., McKee K. L., Lovelock C. E., Cahoon D. R., Saintilan N., Reef R. and Chen L. (2014). How mangrove forests adjust to rising sea level: Tansley review. New Phytologist 202: 19-34.

12. Bird E. C. F. and Barson M. M. (1977). Measurement of physiographic changes on mangrove-fringed estuaries coastlines. Marine Research in Indonesia 18: 73-80.

13. Hansen J., Nazarenko L., Ruedy R., Sato M., Willis J., Del Genio A., Koch D., Lacis A., Lo K., Menon S., Novakov T., Perlwitz J., Russell G., Schmidt G. A. and Tausnev N. (2005). Earth's energy imbalance: Confirmation and implications. Science 308: 14311435 .

14. Meehl G. A., Wasington W. M., Collins W. D., Arblaster J. M., Hu A., Buja L. E., Strand W. G. and Teng H. (2005). How much more global warming and sea level rise? Science 307: 17691772.

15. Gilman E., Ellison J., Jungblat V., VanLavieren H., Wilson L., Areki F., Brighouse G., Bungitak J., Dus E., Henry M., Sauni I Jr., Kilman M., Matthews E., Teariki-Ruatu N., Tukia S. and Yuknavag K. (2006). Adapting to Pacific Island mangrove responses to sea level rise and other climate change effects. Climate Research 32: 161-176.

16. Gilman E. L., Ellison J., Duke N. C. and Field C. (2008). Threats to mangroves from climate change and adaptation options. Aquatic Botany 89: $237-250$.

17. McLeod E. and Salm R. (2006). Managing Mangroves for Resilience to Climate Change. IUCN, Gland, Switzerland.

18. Saad S., Husain M. L., Yaacob R. and Asano T. (1999). Sediment accretion and variability of sedimentological characteristics of a tropical estuarine mangrove: Kemaman, Terengganu, Malaysia. Mangrove and Salt Marshes 3: 5158. 
19. Intergovernmental Panel on Climate Change (IPCC) (2007), Climate Change 2007: The Physical Science Basis: Contribution of Working Group I to the Fourth Assessment Report of the Intergovernmental Panel on Climate Change, (eds. Solomon, S., Qin D., Manning M., Chen Z., Marquis M., Averyt K.B., Tignor M. and Miller H.L.) Cambridge University Press, Cambridge, United Kingdom and New York, NY, USA. 996 pp.

20. Sanders C. J., Smoak J. M., Naidu A. S., Araripe D. R., Sanders L. M. and Patchineelam S. R. (2010). Mangrove forest sedimentation and its reference to sea level rise, Cananeia, Brazil. Environment and Earth Science 60: 12911301.

21. Awang N. A. and Hamid M. R. A. (2013). Sea level rise in Malaysia. Sea level rise adaptation measures. Hydrolink 2: 47-49.

22. NAHRIM (2010). The Study of the Impact of Climate Change on sea Level Rise in Malaysia (Final Report). National Hydraulic Research Institute Malaysia.

23. Jusoff K. (2013). Malaysian mangrove forests and their significance to the coastal marine environment. Polish Journal of Environmental Studies 22: 979-1005.

24. Bennett E. L. and Reynolds C. J. (1993). The value of a mangrove area in Sarawak. Biodiversity and Conservation 2: 359-375.

25. Kasawani I., Kamaruzaman J. and Nurun-Nadhirah M. I. (2007). Biological diversity assessment of Tok Bali mangrove forest, Kelantan, Malaysia. WSEAS Transaction on Environment and Development 2: 37-44.

26. Ong J. E., Gong W. K. and Wong C. H. (1985). Seven years of productivity studies in Malaysian manage mangrove forest than what? In: Coastal and Tidal Wetlands of the Australian Monsoon Region, (eds. Bardsley K.N., Davie J.D.S. and Woodroffe C.D.) Australian National University, Australia. pp. 213-223.

27. Ong J. E., Gong W. K. and Clough B. F. (1995). Structure and productivity of a 20 year old stand of Rhizophora apiculata B1. Mangrove forest. Journal of Biogeography 22: 417-424.
28. Putz F. E. and Chan H. T. (1986). Tree growth, dynamics and productivity in a mature mangrove forest in Malaysia. Forest Ecology and Management 17: 211-230.

29. Gong W. K., Ong J. E., Wong C. H. and Dhanarajan G. (1984). Productivity of mangrove trees and its significance in a managed mangrove ecosystem in Malaysia. In: Proceedings of the Asian Symposium on Mangrove Ecosystem in Research and Management, (eds. Soepadmo E., Rao A.N. and Macintosh D.J.) Kuala Lumpur: University of Malaya. pp. 216-225.

30. Gong W. K. and Ong J. E. (1990). Plant biomass and nutrient flux in a managed mangrove forest in Malaysia. Estuarine, Coastal and Shelf Science 31: 519-530.

31. Kamruzzaman B. Y. and Lokman M. H. (2003). The determination of accretion rate in Setiu mangrove, Malaysia: Thorium-230 versus artificial horizontal marker method. Pertanika Journal of Tropical Agricultural Science 26: 65-71.

32. Mahmood H., Misri K., Sidik B. J. and Saberi O. (2005). Sediment accretion in a protected mangrove forest of Kuala Selangor, Malaysia. Pakistan Journal of Biological Sciences 8: 149-151.

33. Gandaseca S., Rosli N., Ngayop J. and Arianto C. A. (2011). Status of water quality based on the physico-chemical assessment on river water of wildlife sanctuary Sibuti mangrove forest, Miri, Sarawak. American Journal of Environmental Sciences 7: 269-275.

34. Saifullah A. S. M., Abu Hena M. K., Idris M. H., Halima A. R. and Johan I. (2014). Seasonal variation of water characteristics in Kuala Sibuti river estuary in Sarawak, Malaysia. Malaysian Journal of Science 33: 9-22.

35. The Director of Marine Sarawak, Malaysia (DOMSM). (2013). Sarawak Hourly and High \& Low Tide Tables (Including Standard Ports of Sabah). The Sarawak Marine Department (SMD), Malaysia. 
36. Watson J. G. (1928). Mangrove Forests of the Malay Peninsula. Malayan Forest Records. No.6: 129pp.

37. Christiansen T., Wiberg P. L. and Milligan T. G. (2000). Flow and sediment transport on a tidal salt marsh surface. Estuarine, Coastal and Shelf Science 50: 315-331.

38. English S., Wilkinson C. and Baker V. (1994). Survey Manual for Tropical Marine Resources. Australian Institute of Marine Science. Townsville Mail Centre, Australia.

39. Mahmood H., Saberi O., Sidik B. J. and Misri K. (2008). Net primary productivity of Bruguiera parviflora (Wight \&Arn.) dominated mangrove forest at Kuala Selangor, Malaysia. Forest Ecology and Management 255: 179-182.

40. Hedges J. I. and Keil R. G. (1995). Sedimentary organic matter preservation: as assessment and speculative synthesis. Marine Chemistry 49: 81-115.

41. Young B. M. and Harvey L. E. A. (1996). A spatial analysis of the relationship between mangrove (Avicennia marina Var. australasica) physiognomy and sediment accretion in the Hauraki Plains, New Zealand. Estuarine, Coastal and Shelf Science 42: 231-246.

42. Cahoon D. R. and Reed D. J. (1995). Relationships among marsh surface topography, hydro period, and soil accretion in a deteriorating Louisiana salt marsh. Journal of Coastal Research 11: 357-369.

43. Leonard L. A. (1997). Controls of sediment transport and deposition in an incised main land marsh basin, Southeastern North Carolina. Wetlands 17: 263-274.
44. Cahoon D. R., and Lynch J. C. (1997). Vertical accretion and shallow subsidence in a mangrove forest of South Western Florida, U.S.A. Mangroves and Salt Marshes 1: 173-186.

45. Lynch J. C., Meriwether J. R., Mckee B. A., Vera-Herrea F. and Twilley R. R. (1989). Recent accretion in mangrove ecosystem based on ${ }^{137} \mathrm{Cs}$ and ${ }^{210} \mathrm{~Pb}$. Estuaries 12: 264-299.

46. Woodroffe C. D. (1990). The impact of sea level rise on mangrove shorelines. Progress in Physical Geography 14: 483-520.

47. Shahbudin S. (1996). Sediment Accretion and Variability of Sedimentological Characteristics of a Tropical Estuarine Mangrove: Kemaman, Terenggau, MS thesis, University Putra Malaysia.

48. Kamruzzaman B. Y., Leong H. F., Lokman M. H., Ibrahim S. and Amin M. M. (2004). Sediment accretion in the mangrove forests of Bebar River, Pahang, Malaysia: $230^{\text {th }}$ concentration versus artificial marker method. In: Marine Science into the New Millennium: New Perspectives and Challenges (eds. Phang S.E., Ching C.V., Chye H.S., Mokhtar N. and Sim J.O.L.) University of Malaya Maritime Research Centre. Kuala Lumpur, Malaysia, pp. 601-608.

49. Bacon P. R. (1994). Template for evaluation of impacts of sea level rise on Caribbean coastal wetlands. Ecological Engineering 3: 171-186.

50. Snedaker S. C., Meeder J., Ross M. and Ford R. G. (1994). Discussion of Ellison, Joanna C. and Stoddart, David R., 1991. Mangrove ecosystem collapse during predicted sea-level rise: Holocene analogues and implications. Journal of Coastal research 7: 151-165. Journal of Coastal Research 10: 497-498. 